
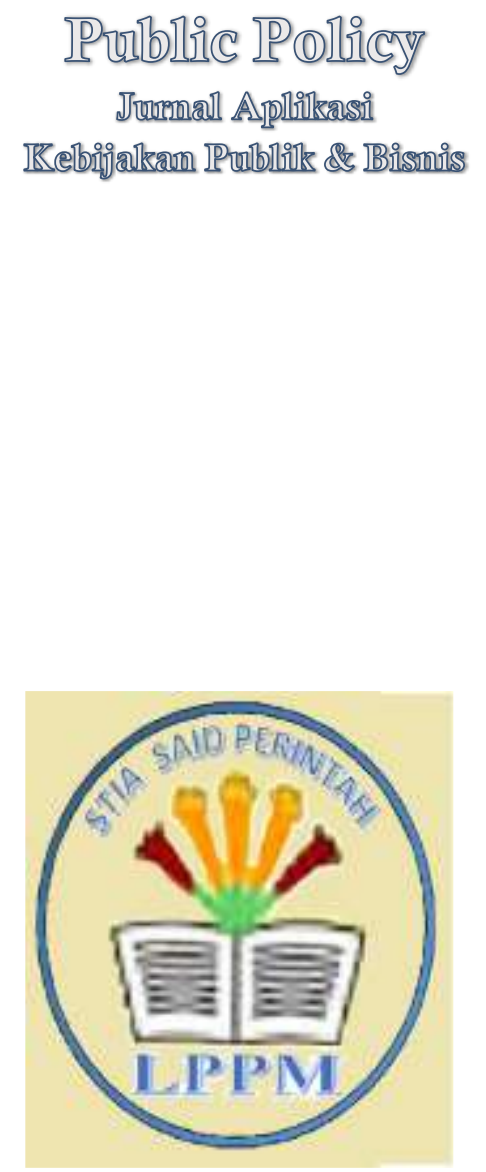

LPPM STIA Said Perintah

Volume 1, No. 2, September 2020

https://stia-saidperintah.e-journal.id/ppj

\section{Karekteristik Tujuan Anggaran Terhadap Kinerja Aparat Pemerintah Daerah pada Organisasi Perangkat Daerah}

\author{
Victor Pattiasina ${ }^{1}$ \\ Muhamad Yamin Noch ${ }^{2}$ \\ (Penulis Korespondensi) \\ Andarias Patiran ${ }^{3}$ \\ Melyanus Bonsapia ${ }^{4}$ \\ 1-2 Universitas Yapis Papua \\ 3,4 Universitas Ottow Geissler Papua \\ abienoch12@gmail.com
}

\begin{abstract}
This research is the criteria concerning the influence of the characteristics of budget objectives on the performance of local government officials in the Keerom regency regional apparatus organization. Testing was carried out on a sample of 73 respondents. The sample method used was Porpusive sampling. Data collection was carried out by direct survey. Testing testing is tested empirically using multiple regression. The results showed that budget preparation had a positive and insignificant effect on the performance of local government officials in Keerom Regency. Budget feedback did not have a positive and significant effect on the performance of local government officials in Keerom Regency, local governments evaluated that the budget had no positive and significant effect on the performance of local government officials in Keerom Regency. , Clarity of budget targets has a positive and significant effect on the performance of local government officials in Keerom Regency. The difficulty of budget objectives has a positive and significant effect on the performance of local government officials in Keerom Regency and participation in budget formulation, budget evaluation, clarity of budget targets and difficulty of simultaneous budget objectives on the performance of government officials. Keerom Regency area.

Keywords : Participation in Budgeting, Budget Feedback, Clarity of Budget Targets, Difficulty of Budget Targets and Performance of Local Government Officials.
\end{abstract}




\section{Latar Belakang}

Kebijakan otonomi daerah pada dasarnya diarahkan untuk mendorong peningkatan kapasitas pemerintah daerah dalam memberikan pelayanan kepada masyarakat secara lebih efektif dan efisien. Kedekatan organisasi pemerintah pada level daerah diharapkan lebih mampu menerima aspirasi riil masyarakat tentang pelayanan apa yang dibutuhkan. Oleh karena itu, diharapkan ada input yang diperoleh dalam rangka perencanaan pembangunan sehingga tidak ada kesenjangan antara perencanaan pembangunan yang dilaksanakan pemerintah baik program dan anggaran dengan kebutuhan riil masyarakat.

Fenomena pada Pemerintah Kabupaten Keerom yang terjadi di mana kalangan aparatur sipil Negara yang bekerja di Kabupaten Keerom, Provinsi Papua mempertanyakan insentif selama enam bulan yang belum di bayarkan, salah satu perwakilan ASN dari dinas Pertanian Keerom mengatakan permasalahan yang dihadapi ASN dalam melaksanakan tugasnya di Pemkab Keerom cukup banyak dan tak ada solusi termasuk soal pembayaran insentif. Menurutnya insentif para ASN selama enam bulan belum di bayarkan, termasuk insentif bagi tenagah kesehatan yang hingga kini belum juga di bayarkan, (https://papua.antaranews.com. 2020).

Terkait perbedaan sifat dan karakteristik sektor publik dengan sektor bisnis atau privat dapat Nampak jelas melalui beberapa factor antara lain tujuan organisasi, sumber pembiayaan, pola pertanggungjawaban, struktur organisasi, karakteristik anggaran, stakeholder yang dipengaruhi, dan sistem akuntansi yang digunakan, serta tidak menutup kemungkinan faktor-faktor lainnya. (Mardiasmo, 2009).

Salah satu faktor yang mempengaruhi kinerja aparatur pemerintah daerah yang pertama adalah partisipasi penyusunan anggaran. (Brownell, 1986) menjelaskan partisipasi anggaran adalah keikutsertaan individu berupa perilaku, pekerjaan, dan aktifitas oleh aparat pemerintah selama proses penyusunan anggaran tersebut berlangsung. Beberapa penelitian mengenai hubungan partisipasi penyusunan anggaran terhadap kinerja pemerintah daerahmasih menunjukkan hasil yang tidak konsisten, dimana kajian yang dilakukan (Solina, 2014) hasil penelitian menemukan partisipasi penyusunan anggaran berpengaruh signifikan terhadap kinerja aparatur pemerintah daerah. Hasil penelitian ini didukung oleh kajian (Sujana, 2014) dimana hasil penelitian menemukan Partisipasi Anggaran berpengaruh signifikan terhadap kinerja pemerintah daerah. Namun hasil penelitian ini bertolak belakang dengan kajian (Widiyastuti, 2015) 
hasil penelitian menunjukkan Partisipasi Penyusunan Anggaran tidak berpengaruh signifikan terhadap Kinerja pemerintah daerah. Hasil penelitian ini sejalan dengan hasil kajian (Muthaher, 2007) yang menemukan hasil tidak signifikan antara Partisipasi Penyusunan Anggaran dengan Kinerja Aparat Pemerintah Daerah.

Faktor kedua yang berpengaruh terhadap kinerja pemerintah daerah adalah umpan balik anggaran. Menurut (Kenis, 1979) adanya umpan balik anggaran akan memudahkan individu untuk menyusun target-target anggaran. dimana, target-target anggaran yang disusun akan sesuai dengan tujuan yang ingin dicapai organisasi.Pernayataan diatas sejalan dengan kajian yang dilakukan oleh (Azis, 2011), hasil penelitian menunjukan umpan balik anggaran dapat dibuktikan secara signifikan mempunyai pengaruh positif terhadap kinerja pemerintah daerah. Hasil penelitian ini di dukung oleh kajian (Boangmanalu, 2014) hasil penelitian menunjukan secara parsial dan secara simultan bahwa terdapat pengaruh yang signifikan dari Partisipasi Penyusunan Anggaran, Umpan Balik Anggaran, dan Motivasi berpengaruh terhadap Kinerja pemerintah daerah SKPD Pada Kabupaten Pakpak Bharat

Faktor ketiga yang dapat mempegaruhi kinerja pemerintah adalah Evaluasi anggaran dimana evaluasi anggaran menunjuk pada luasnya perbedaan anggaran yang digunakan kembali oleh individu pimpinan departemen dan digunakan dalam evaluasi kinerja mereka. Pernyataan sejalan dengan kajian yang dilakukan oleh (Sujana, 2014). Hasil penelitian menunjukan bahwa Evaluasi anggaran berpengaruh positif terhadap kinerja aparat pemerintah Daerah

Faktor keempat yang dapat mempengaruhi kinerja pemerintah daerah adalah kejelasan sasaran anggaran (Sisdyani, 2016) Adanya kejelasan sasaran anggaran akan membantu manajer untuk mendapatkan informasi mengenai kegagalan dan keberhasilan pe merintah, sehingga manajer akan dapat menentu kan tujuan anggaran dengan jelas dan spesifik. Pernyataan diatas dapat didukung dengan Penelitian yang dilakukan oleh (Widiyastuti, 2015). Hasil Penelitian menunjukan bahwa Kejelasan Sasaran Anggaran berpengaruh signifikan terhadap kinerja pemerintah daerah.

Berdasarkan pemaparan konsep dan realita yang terjadi dan hasil kajian-kajian empiris di atas ternyata menunjukan adanya ambivalensi hasil penelitian. Artinya ambivalensi atau kontradiksi hasil penelitian tersebut sebenarnya adalah research gap (kesenjangan penelitian). Sehingga dari kontradiksi dan realita tersebut membuat peneliti mau melalukan penelitian pada lingkungan Pemerintah Kabupaten Keerom dan 
di dalam penelitian ini ada Kebaruan penelitian ini dari penelitian sebelumnya adalah ditambahkan variabel kesulitan tujuan anggaran jika di kaitkan dengan Grand Thory yang di gunakan adalah teori kontijensi dimana di perlukan pendekatan kontijensi dalam mengevaluasi factor-faktor kondisional yang kemungkinan menyebabkan kinerja apparat menjadi lebih efektif.

Berdasarkan pemaparan konsep dan realita yang terjadi dan hasil kajian-kajian empiris di atas ternyata menunjukan adanya ambivalensi hasil penelitian. Artinya ambivalensi atau kontradiksi hasil penelitian tersebut sebenarnya adalah research gap (kesenjangan penelitian). Sehingga dari kontradiksi dan realita tersebut membuat peneliti mau melalukan penelitian pada lingkungan Pemerintah Kabupaten Keerom. Rumusan masalah dalam penelitian ini adalah apakah partisipasi anggaran, umpan balik, evaluasi anggaran, kejelasan anggaran dan kesulitan tujuan anggaran secara parsial dan simultan berpengaruh terhadap kinerja aparat pemerintah daerah. Tujuan dari penelitian ini adalah untuk menganalisis dampak variable partisipasi anggaran, umpan balik, evaluasi anggaran, kejelasan anggaran dan kesulitan tujuan anggaran secara parsial dan simultan berpengaruh terhadap kinerja aparat pemerintah daerah

\section{Kerangka Teoritis dan Pengembangan Hipotesa}

Berdasarkan uraian yang telah diteliti sebelumnya maka dalam penelitian ini akan menguji pengaruh karaakteristik tujuan anggaran terhadap kinerja aparatur pemerintah daerah Kabupaten Keerom. Gambaran kerangka pemikiran dalam penelitian ini adalah sebagai berikut:

\section{Kerangka Konseptual}

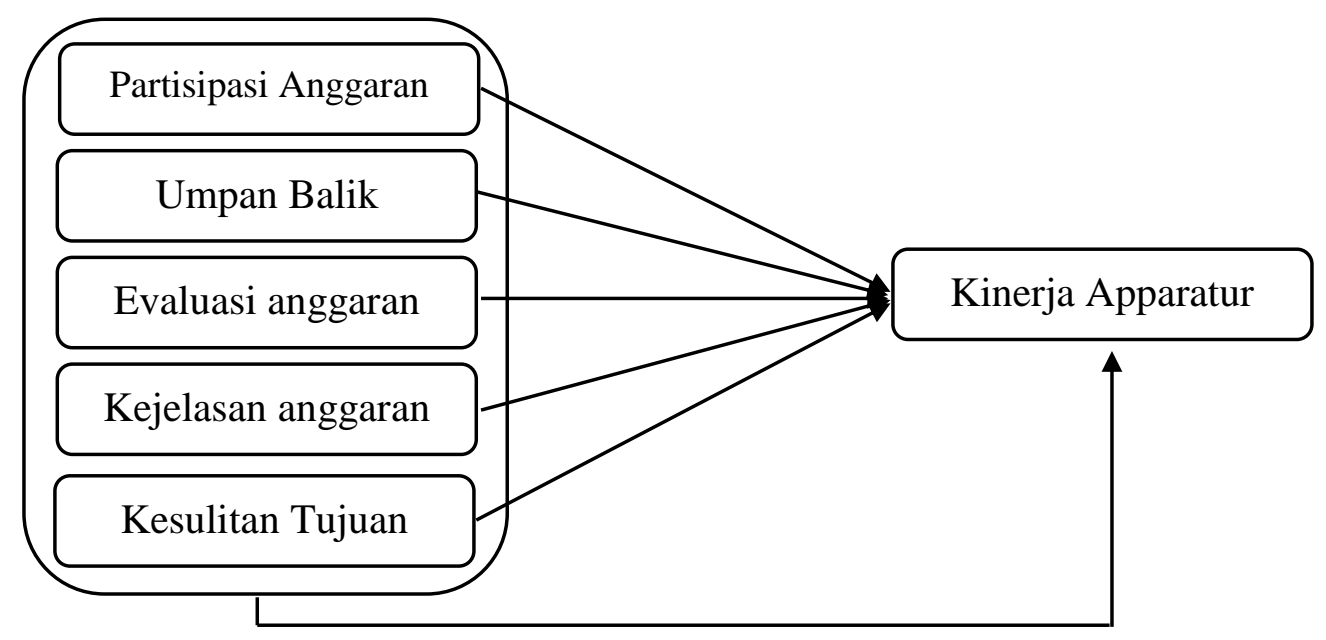




\section{Pengaruh partisipasi anggaran secara parsial terhadap kinerja aparat pemerintah daerah}

Dalam suatu organisasi mengatakan bahwa partisipasi atau keterlibatan individu yang bersifat mental dan emosional dalam suatu kelompok bagi pencapaian tujuan bersama dan berbagi tanggungjawab bersama. Pernyataan di atas dapat didukung oleh penelitian (Sari, 2020) dan (Purwandani, 2012). Hasil penelitian ini menunjukan bahwa partisipasi penyusunan anggaran berpengaruh positif terhadap kinerja aparat. Berdasarkan teori dan kajian penelitian yang telah dijelaskan di atas maka hipotesis yang diajukan adalah sebagai berikut;

$\mathrm{H}_{1}$; Partisipasi penyusunan anggaran berpengaruh terhadap kinerja aparat pemerintah daerah Kabupaten Keerom.

\section{Pengaruh umpan balik anggaran secara parsial terhadap kinerja aparat pemerintah daerah}

(Kenis, 1979) Selanjutnya umpan balik terhadap tingkat sasaran anggaran yang dicapai merupakan salah satu variabel penting untuk memberikan motivasi. Dalam hal ini presiden republik Indonesia memberikan anggaran kepada pemerintah provinsi papua berupa program pembangunan infrastruktur yang nantinya umpan balik dari anggaran tersebut bisa meningkatkan pendapatan bagi Negara yang terkandung dalam kinerja manajerial yang berkompetesi sehingga dapat memberikan kepuasan kerja dan ketidakpastian lingkungan kinerja manajerial.

Pernyataan di atas dapat di dukung oleh penelitian (Sari, 2020). Hasil penelitian menunjukan bahwa Umpan balik anggaran berpengaruh positif terhadap kinerja aparat pemerintah Daerah. Namun bertolak belakang oleh penelitian (Vince, 2016). Umpan balik anggaran tidak berpengaruh signifikan terhadap kinerja. Berdasarkan teori Kontijensi dan kajian penelitian yang telah dijelaskan di atas maka hipotesis yang diajukan adalah sebagai berikut;

$\mathrm{H}_{2}$; Umpan balik anggaran berpengaruh terhadap kinerja aparat pemerintah daerah Kabupaten Keerom.

\section{Pengaruh evaluasi anggaran secara parsial terhadap kinerja apparat pemerintah daerah}

Evaluasi anggaran dapat menunjukan selisih anggaran yang disusun dan pada kenyataanya. Dengan evaluasi anggaran dapat diketahui apakah kinerja aparat tersebut 
dalam menyusun anggaran sudah baik atau belum. Pernyataan ini didukung oleh penelitian penelitian (Naipospos, 2015) evaluasi anggaran berpengaruh positif terhadap kinerja aparat pemerintah kota Pekanbaru. Berdasarkan teori dan kajian penelitian yang telah dijelaskan di atas maka hipotesis yang diajukan adalah sebagai berikut;

$\mathrm{H}_{3}$; Evaluasi anggaran berpengaruh terhadap kinerja aparat pemerintah daerah Kabupaten Keerom.

\section{Pengaruh kejelasan anggaran secara parsial terhadap kinerja apparat pemerintah daerah}

Adanya sasaran anggaran yang jelas, maka akan mempermudah untuk dipertanggungjawabkan keberhasilan atau kegagalan pelaksanaan tugas organisasi dalam rangka mencapai tujuan dan sasaran yang telah ditetapkan sebelumnya. Pernyataan diatas di dukung oleh peneltian (Sari, 2020) dan (Desak Putu Intan Permata Sari, Ni Kadek Sinarwati, 2014). Hasil penelitian menunjukan bahwa pengaruh variabel kejelasan sasaran anggaran terhadap kinerja aparatur pemerintah daerah. Berdasarkan teori dan kajian penelitian yang telah dijelaskan di atas maka hipotesis yang diajukan adalah sebagai berikut;

$\mathrm{H}_{4} ;$ Kejelasan Sasaran anggaran berpengaruh terhadap kinerja aparat pemerintah daerah Kabupaten Keerom.

\section{Pengaruh kesulitan tujuan anggaran secara parsial terhadap kinerja apparat pemerintah daerah}

Menurut (Dido, 2011) anggaran yang ideal adalah anggaran yang dapat memberikan tantangan namun bisa dicapai. Pernyataan di atas dapat didukung oleh penelitian (Fransisca, 2012) yang mengemukakan kesulitan tujuan anggaran berpengaruh positif terhadap kinerja aparat pemerintah Kota Yogyakarta. Berdasarkan teori dan kajian penelitian yang telah dijelaskan di atas maka hipotesis yang diajukan adalah sebagai berikut;

$\mathrm{H}_{5}$; Kesulitan tujuan anggaran berpengaruh terhadap kinerja aparat pemerintah daerah Kabupaten Keerom.

Pengaruh partisipasi anggaran, umpan balik anggaran, evaluasi anggaran, kejelasan anggaran, kesulitasn tujuan anggaran secara simultan terhadap kinerja aparatur pemerintah daerah

Partisipasi anggaran menunjukkan pada sejauh mana aparat pemerintah daerah berpartisipasi dalam penyusunan anggaran. Partisipasi anggaran secara umum dapat 
meningkatkan kinerja aparat yang pada akhirnya juga dapat meningkatkan efektifitas organisasi. Pernyataan di atas dapat di dukung ole penelitian (Sari, 2020). Hasil penelitian menunjukan bahwa secara simultan partisipasi anggaran, umpan balik anggaran, evaluasi anggaran, kejelasan anggaran, kesulitasn tujuan anggaran secara simultan berpengaruh terhadap kinerja aparatur pemerintah daerah. Berdasarkan teori dan kajian penelitian yang telah dijelaskan di atas maka hipotesis yang diajukan adalah sebagai berikut;

$\mathrm{H}_{5}$; Partisipasi anggaran, umpan balik anggaran, evaluasi anggaran, kejelasan anggaran, kesulitasn tujuan anggaran secara simultan berpengaruh positif dan signifikan terhadap kinerja aparatur pemerintah daerah Kabupaten Keerom.

\section{Metode Penelitian}

Jenis penelitian yang digunakan dalam penelitian ini adalah jenis penelitian asosiatif merupakan penelitian yang bertujuan untuk mengetahui pengaruh ataupun hubungan antara dua variabel atau lebih. Rancangan penelitian ini tergolong pada penelitian kausatif. Penelitian kausatif berguna untuk menganalisis pengaruh antara satu variabel dengan variabel lain (Sugiyono, 2009). Pengumpulan data penelitian ini menggunakan metode kuisioner. Kuisioner merupakan teknik pengumpulan data yang dilakukan dengan cara memberikan seperangkat pertanyaan tertulis kepada responden untuk di jawabnya (Sugiyono, 2009).

Populasi dalam penelitian ini adalah seluruh pegawai ASN yang bekerja pada bagian akuntansi/penatausahaan pada Organisasi Perangkat Daerah Pemerintah Kabupaten Keerom dengan jumlah 28 (OPD). Pengambilan sampel (sampling method) terhadap responden dilakukan secara purposive. Purposive sampling digunakan karena informasi yang akan diambil berasal dari sumber berdasarkan kriteria yang telah ditetapkan penelitian (Indriasari, 2008). Adapun kriteri sampel yang di jelaskan responden dalam penelitian ini adalah Kepala Instansi, Kepala bagian/sub bagian Keuangan dan penganggaran. Berdasarkan kriteria yang telah ditentukan maka sampel dalam penelitian ini adalah diambil dari masing-masing 3 responden pada Organisasi Perangkat Daerah di Kabupaten Keerom, sehingga total sampel dalam penelitian ini berjumlah ( 3 responden x 28 OPD) yang di ambil dari kepala instansi, kepala bagian/sub bagian keuangan dan bagian penggangaran, sehingga total sampel dalam penelitian ini adalah 84 responden. 
Variabel yang diteliti dalam kajian ini antara lain; kinerja aparatur pemerintah daerah yaitu: merupakan kegiatan yang penting dalam perusahaan atau organisasi yang dipengaruhi oleh beberapa faktor untuk mencapai tingkat efektif dan efisien untuk mendapatkan hasil yang maksimal dalam pencapaian tujuan organisasi. (Wahyuni, 2016). Variabel selanjutnya adalah yaitu (Bangun, 2009) menjelaskan partisipasi sebagai suatu proses pengambilan keputusan bersama oleh dua pihak atau lebih yang mempunyai dampak masa depan bagi pembuat dan penerima keputusan.

Variabel berikutnya adalah umpan balik anggaran yaitu Umpan balik anggaran digunakan sebagai alat ukur sejauh mana individu mengetahui pencapaian dari tujuan anggaran dan kegiatan yang telah dilakukan. Variabel umpan balik diukur dengan mengadopsi instrumen dari (Istiyani, 2009). Variabel selanjutnya adalah Evaluasi Anggaran Yaitu: Evaluasi anggaran dapat diartikan sejauh mana selisih anggaran dengan apa yang telah dicapai dalam progam dan kegiatan SKPD yang digunakan oleh pimpinan untuk mengevaluasi kinerja individu apakah sudah baik atau belum dalam hal penyusunan dan realisasi anggaran. Instrumen pengukuran dalam penelitian ini mengadopsi dari (Istiyani, 2009) yang mengadopsi instrumen dari (Kenis, 1979), Variabel evaluasi anggaran diukur dengan mengadopsi instrumen dari (Istiyani, 2009).

Variabel selanjutnya adalah kejelasan sasaran anggaran yaitu sejauhmana tujuan anggaran ditetapkan secara jelas dan spesifik dengan tujuan agar anggaran tersebut dapat dimengerti oleh orang yang bertanggung jawab atas pencapaian sasaran tersebut. Variabel kejelasan anggaran diukur dengan mengadopsi instrumen dari (Istiyani, 2009). Variabel yang terakhir adalah kesulitas tujuan anggaran yaitu menurut (Dido, 2011) anggaran yang ideal adalah anggaran yang menentang namun bisa dicapai. Dalam istilah statistik, hal ini dapat diartikan bahwa seorang manajer yang bekerja dengan cukup baik mempunyai kesempatan paling tidak $50 \%$ untuk mencapai jumlah anggaran. Seluruh pengukuran variabel dilakukan dengan skala likert 1-5 (1; sangat tidak setuju sampai dengan 5; sangat setuju).

Analisis data penelitian diawali dengan pengujian instrument penelitian yakni uji validitas dan reliabilitas. Uji validitas penelitian ini menggunakan uji validitas konstruk yang dilakukan dengan teknik korelasi antara skor butir pertanyaan dalam variabel yang diamati dengan skor total. Selanjutnya diterapkan rumus korelasi product-moment dengan taraf signifikansi 5\% dari nilai kritis. Rumus korelasi product-moment menurut (Sugiyono, 2015) adalah uji reliabilitas, uji asumsi klasik, dan uji normalitas. 
Uji reliabilitas dilakukan untuk menghasilkan ukuran pernyataan yang konsisten. Reliabilitas menurut (Sugiyono, 2015) adalah derajat konsistensi atau kekonstanan suatu data dalam selang waktu tertentu. Pengukuran reliabilitas, dalam penelitian ini, dilakukan dengan cara pengukuran satu kali dengan SPSS 23.00 Cronbach Alpha Statistical Test yang didasarkan pada item terstandarisasi. Variabel konstruktor dinyatakan reliabel jika memberikan nilai Cronbach Alpha berdasarkan butir terstandarisasi> 0,6. Tampilan keluaran SPSS menunjukkan bahwa konstruk variabel memberikan nilai Cronbach Alpha berdasarkan item terstandardisasi> 0,70 yang menurut (Ghozali, 2018) dapat dikatakan reliabel. Variabel ini dapat di katakana baik dengan melihat standarnisasi di atas.

Selanjutnya analisis data penelitian menggunakan analisis regresi linier berganda. Menurut (Sekaran, 2008), untuk melakukan analisis regresi berganda perlu dilakukan pengujian asumsi-asumsi analisis yaitu: normalitas, multikolinearitas, dan heteroskedastisitas. Sehingga data yang terkumpul dapat bermakna dan bermanfaat guna menghasilkan BLUE (Best Linear Unlimited Estimator). Selanjutnya, tujuan asumsi normalitas data adalah untuk menguji apakah dalam model regresi, variabel dependen, variabel independen, atau keduanya, berdistribusi normal atau tidak. Model regresi yang baik adalah model yang berdistribusi normal atau mendekati normal (Ghozali, 2018). Normalitas itu sendiri pada prinsipnya dapat dideteksi dengan melihat sebaran data (titik), pada sumbu diagonal pada grafik atau dengan melihat histogram dari residualnya.

\section{Hasil Penelitian dan Pembahasan}

\section{Pengaruh Partisipasi Penyusunan Angagran Terhadap Kinerja Aparatur Pemerintah Daerah}

Berdasarkan hasil penelitian dapat dilihat bahwa partisipasi penyusunan anggaran tingkat signifikansi yang ditetapkan $(0,063>0,050)$ maka hipotesis pertama yang menyatakan bahwa ada pengaruh antara partisipasi penyusunan anggaran terhadap kinerja aparatur pemerintah daerah Kabupaten Keerom diterima (terima Ha dan tolak $\mathrm{HO})$.

Hasil pengujian hipotesis pertama terbukti partisipasi penyusunan anggaran berpengaruh secara positif dan tidak signifikan terhadap kinerja aparatur pemerintah daerah. Hal ini dapat di justifikasi partisipasi penyusunan anggaran dapat meningkatkan kinerja aparatur pemerintah daerah. Artinya dengan ketrlibatan atau pertisipasi dalam penyusunana anggaran yang baik maka berdampak pada kinerja aparatur pemerintah 
daerah Kabupaten Keerom yang baik pula. (Bangun, 2009) dalam tulisannya mengemukakan partisipasi sebagai suatu proses pengambilan keputusan bersama oleh dua pihak atau lebih yang mempunyai dampak masa depan bagi pembuat dan penerima keputusan dan mengarah pada seberapa besar tingkat keterlibatan aparat pemerintah daerah dalam menyusun anggaran daerah serta pelaksanaannya untuk mencapai target anggaran tersebut. Partisipasi aparat pemerintah daerah Kabupaten Keerom dalam proses penganggaran pemerintah daerah mengarah pada seberapa besar tingkat keterlibatan aparat pemerintah daerah dalam menyusun anggaran daerah serta pelaksanaan-nya untuk mencapai target anggaran

Hasil penelitian ini sejalan dengan hasil (Sari, 2020) partisipasi anggaran berpengaruh positif terhadap kinerja aparat pemerintah daerah. Namun hasil penelitian (Sari, 2020) bertolak belakang dengan hasil penelitian (Widyarini, 2015). Dimana hasil penelitiannya menunjukan bahwa Partisipasi Penyusunan Anggaran tidak berpengaruh signifikan terhadap Kinerja pemerintah daerah.

\section{Pengaruh Umpan Balik Anggaran Terhadap Kinerja Aparatur Pemerintah Daerah}

Berdasarkan hasil penelitian dapat dilihat bahwa partisipasi penyusunan anggaran dengan tingkat signifikansi yang ditetapkan $(0,702>0,050)$. Berdasarkan analisis ini maka hipotesis kedua yang menyatakan bahwa tidak ada pengaruh antara umpan balik anggaran terhadap kinerja aparatur pemerintah daerah Kabupaten Keerom ditolak (tolak $\mathrm{Ha}$ dan terima $\mathrm{HO}$ ).

Hasil pengujian hipotesis kedua terbukti umpan balik anggaran tidak berpengaruh secara positif dan signifikan terhadap kinerja aparatur pemerintah daerah. Hal ini dapat di justifikasi umpan balik anggaran tidak dapat meningkatkan kinerja aparatur pemerintah daerah. Artinya Umpan balik ini antara lain meliputi pemberian saran atas prestasi yang hendak dicapai, memberikan evaluasi pada proses perencanaan anggaran, dan perbaikan sikap aparat setelah mendapat umpan balik tersebut. Dengan adanya umpan balik aparat pemda memiliki insentif dan dorongan untuk mencapai kinerja yang lebih baik, tetapi dalam 6 bulan terakhir ini ASN tidak mendapatkan Insentif dengan baik Sehingga berdampak pada malasuntuk bekerja sehingga prestasi kerja pegawai menurun.

Umpan balik anggaran menunjukan hasil atau sejauh mana tujuan anggaran dapat dicapai. Karena umpan balik anggaran dapat menunjukan seberapa efektif kinerja aparat 
dalam merealisasikan anggaran. Dengan adanya umpan balik anggaran maka dapat diketahui seberapa besar kinerja aparat dalam tanggung jawabnya merealisasikan anggaran yang telah disusun. Diharapkan umpan balik anggaran berpengaruh terhadap kinerja aparat pemerintah daerah.

Pernyataan di atas dapat didukung oleh penelitian yang di lakukan (Sari, 2020). Hasil penelitan menunjukan bahwa umpan balik anggaran berpengaruh positif terhadap kinerja aparat pemerintah daerah. Namun hasil penelitian (Sari, 2020) bertolak belakang dengan hasil penelitian (Taufik, 2016). Hasil menunjukan bahwa umpan balik anggaran tidak berpengaruh signifikan terhadap kinerja.

\section{Pengaruh Evaluasi Anggaran Terhadap Kinerja Aparatur Pemerintah Daerah}

Berdasarkan hasil penelitian dapat dilihat bahwa evaluasi anggaran dengan tingkat signifikansi yang ditetapkan $(0,485>0,050)$. Berdasarkan analisis ini maka hipotesis ketiga yang menyatakan bahwa tidak ada pengaruh antara evaluasi anggaran terhadap kinerja aparatur pemerintah daerah Kabupaten Keerom ditolak (tolak Ha dan terima H0).

Hasil pengujian hipotesis ketiga terbukti evaluasi anggaran tidak berpengaruh secara positif dan signifikan terhadap kinerja aparatur pemerintah daerah. Hal ini dapat di justifikasi evaluasi anggaran yang dilakukan pada Pemda Kabupaten keerom kurang efektif dalam arti evaluasi anggaran belum dapat mengungkap sejauh mana pertanggungjawaban aparat dalam melaksanakan tugasnya sehingga evaluasi anggaran dapat mempengaruhi kinerja aparat pemerintah daerah Kabupaten keerom.

Evaluasi anggaran dapat menunjukan selisih anggaran yang disusun dan pada kenyataanya. Dengan evaluasi anggaran dapat diketahui apakah kinerja aparat tersebut dalam menyusun anggaran sudah baik atau belum. Sehingga evaluasi anggaran dapat digunakan untuk evaluasi kinerja. Karena evaluasi anggaran dapat digunakan untuk evaluasi kinerja diharapkan secara langsung evaluasi anggaran dapat mempengaruhi kinerja aparat pemerintah daerah. Pernyataan diatas didukung oleh penelitian (Sari, 2020) dan (Taufik, 2016) yang menunjukan bahwa secara parsial proses evaluasi anggaran berpengaruh signifikan terhadap kinerja aparatur pemerintah daerah.

\section{Pengaruh Kejelasan Sasaran Anggaran Terhadap Kinerja Aparatur Pemerintah Daerah}

Berdasarkan hasil penelitian dapat dilihat bahwa kejelasan sasaran anggaran dengan tingkat signifikansi yang ditetapkan $(0,042<0,050)$. Berdasarkan analisis ini maka hipotesis keempat yang menyatakan bahwa ada pengaruh antara kejelasan 
sasaran anggaran terhadap kinerja aparatur pemerintah daerah Kabupaten Keerom diterima (terima $\mathrm{Ha}$ dan tolak $\mathrm{H} 0$ ).

Hasil analisis membuktikan bahwa kejelasan sasaran anggaran berpengaruh positif dan signifikan terhadap kinerja aparatur pemerintah daerah. Hal ini dapat di justifikasi Uraian statistik deskritif menjelaskan bahwa aparat pemerintah di Kabupaten keerom memiliki kemampuan untuk merumuskan tujuan anggaran yang jelas, spesifik dan dapat dapat dimengerti. Kejelasan tujuan anggaran mendorong aparat di Kabupaten Keerom.

Kejelasan tujuan anggaran menunjukan seberapa efektifnya, seberapa efisiensinya tujuan anggaran yang disusun. Apabila anggaran memiliki tujuan yang jelas maka pencapaian tujuan semakin jelas sehingga mempengaruhi kinerja aparat dalam melaksanakan tanggung jawabnya. Kejelasan tujuan anggaran menyebabkan aparat pemerintah daerah semakin mengerti target-target yang akan dicapai dimasa datang.

Kejelasan tujuan anggaran menunjukkan luasnya tujuan anggaran yang dinyatakan secara spesifik, jelas, dan dimengerti oleh siapa saja yang bertanggungjawab. (Syafrial, 2009) menguraikan bahwa penetapan tujuan spesifik akan lebih produktif dari pada tidak menetapkan tujuan spesifik. Produktivitas tersebut akan mampu memberikan pengaruh yang signifikan terhadap peningkatan kinerja organisasi. Pernyataan diatas sejalan dengan hasil kajian dalam penelitian ini (Widyarini, 2015) dan (Nugraeni, 2015). Hasil menunjukan bahwa kejelasan sasaran anggaran berpengaruh signifikan terhadap kinerja pemerintah daerah.

\section{Pengaruh Kesulitan Tujuan Anggaran Terhadap Kinerja Aparatur Pemerintah Daerah}

Berdasarkan hasil penelitian dapat dilihat bahwa kesulitan tujuan anggaran dengan tingkat signifikansi yang ditetapkan $(0,006<0,050)$. Berdasarkan analisis ini maka hipotesis kelima yang menyatakan bahwa ada pengaruh antara kesulitan tujuan anggaran terhadap kinerja aparatur pemerintah daerah Kabupaten Keerom diterima (terima Ha dan tolak $\mathrm{HO}$ ).

Hasil analisis membuktikan bahwa kesulitan tujuan anggaran berpengaruh positif dan signifikan terhadap kinerja aparatur pemerintah daerah. Hal ini berarti bahwa kinerja aparat pemda Kabupaten Keerom dipengaruhi oleh kesulitan tujuan anggaran, sehingga dalam mempersiapkan penyusunan anggaran selalu memperhatikan mudah atau sulitnya anggaran yang akan dicapai. 
Hal ini juga sesuai dengan teori yang dikemukan menurut Anthony dalam (Dido, 2011) anggaran yang ideal adalah anggaran yang menentang namun bisa dicapai. Dalam istilah statistik, hal ini dapat diartikan bahwa seorang manajer yang bekerja dengan cukup baik mempunyai kesempatan paling tidak 50\% untuk mencapai jumlah anggaran. Terdapat pemanfaatan umum bahwa anggaran yang terlalu sulit dicapai mengakibatkan para pelaksana termotivasi, akan tetapi anggaran yang terlalu mudah dicapai mengakibatkan para pelaksana tidak merasa ditantang untuk berprestasi karena tanpa bekerja giatpun kemungkinan akan timbul penyimpangn yang menguntungkan dalam jumlah besar.

Pernyataan diatas sejalan dengan hasil kajian dalam penelitian ini (Taufik, 2016). Hasil menunjukan bahwa kesulitan tujuan anggaran berpengaruh negatif namun tidak berpengaruh signifikan terhadap kinerja apparat pemerintah daerah. Namun hasil penelitan (Taufik, 2016). Bertolak belakang dengan penelitan (Nina, 2014) hasil menunjukan bahwa kesulitan tujuan anggaran tidak berpengaruh negatif namun tidak berpengaruh signifikan terhadap kinerja apparat pemerintah daerah.

\section{Pengaruh Partisipasi Peyusunan Anggaran, Umpan Balik Anggaran, Evaluasi Anggaran, Kejelasan Sasaran Anggaran Dan Kesulitan Tujuan Anggaran Secara Simultan Terhadap Kinerja Aparatur Pemerintah Daerah.}

Hipotesis keenam atau yang terakhir dalam penelitian ini menyatakan bahwa "Partisipasi Peyusunan Anggaran, Umpan Balik Anggaran, Evaluasi Anggaran, Kejelasan Sasaran Anggaran Dan Kesulitan Tujuan Anggaran Secara Simultan Terhadap Kinerja Aparatur Pemerintah Daerah". Berdasarkan hasil analisis pada Tabel 4.15 terlihat bahwa nilai $\mathrm{F}$ hitung adalah sebesar 54,356 yang adalah lebih besar dari besarnya $\mathrm{F}$ tabel yang hanya sebesar 2.286 dengan signifikansi 0.000 yang juga $<$ dari nilai $p$ value 0.05 sehingga $\mathrm{Ha}$ diterima dan $\mathrm{H}_{0}$ ditolak artinya bahwa Partisipasi Peyusunan Anggaran, Umpan Balik Anggaran, Evaluasi Anggaran, Kejelasan Sasaran Anggaran Dan Kesulitan Tujuan Anggaran Secara Simultan Terhadap Kinerja Aparatur Pemerintah Daerah.

Hasil peneitian secara simultan di atas sejalan dengan penelitian (Nina, 2014). Menunjukan bahwa Hasil Penelitian Partisipasi Peyusunan Anggaran, Umpan Balik Anggaran, Evaluasi Anggaran, Kejelasan Sasaran Anggaran, Kesulitan Tujuan Anggaran dan keadilan prosedural Secara Simultan Terhadap Kinerja Aparatur Pemerintah Daerah. 


\section{Penutup}

\section{Kesimpulan}

Berdasarkan pembahasan hasil penelitian maka kesimpulan yang dapat disampaikan melalui penelitian ini adalah sebagai berikut; 1) Partisipasi penyusunan anggaran berpengaruh positif dan tidak signifikan terhadap kinerja aparatur pemerintah daerah Kabupaten Keerom. 2). Umpan balik anggaran tidak berpengaruh positif dan signifikan terhadap kinerja aparatur pemerintah daerah Kabupaten Keerom. 3). Evaluasi anggaran tidak berpengaruh positif dan signifikan terhadap kinerja aparatur pemerintah daerah Kabupaten Keerom. 4). Kejelasan sasaran anggaran berpengaruh positif dan signifikan terhadap kinerja aparatur pemerintah daerah Kabupaten Keerom. 5). Kesulitas tujuan anggaran berpengaruh positif dan signifikan terhadap kinerja aparatur pemerintah daerah Kabupaten Keerom. 6). Partisipasi peyusunan anggaran, umpan balik anggaran, evaluasi anggaran, kejelasan sasaran anggaran dan kesulitan tujuan anggaran secara simultan terhadap kinerja aparatur pemerintah daerah Kabupaten Keerom.

\section{Saran}

Saran bagi Pemerintah Daerah, dalam meningkatkan kinerja aparatur pemerintah daerahnya harus mempunyai peranan yang sangat penting dalam peningkatan motivasi pegawai ditempat kerja. Hasil penelitian ini diharapkan mampu memberikan konstribusi terhadap pengembangan literatur akuntansi pemerintahan dengan melibatkan Sumber Daya Manusia yang berkompeten di bidangnya masing-masing dalam pencapaian tujuan yang transparan dan akuntabilitas. Pada Penelitian berikutnya dapat menambahkan variabel yang tidak termasuk dalam penelitian ini, seperti pengawasan anggaran.

\section{Daftar Pustaka}

Azis. (2011). Analisis pengaruh partisipasi penyusunan anggaran, kejelasan anggaran dan umpan balik terhadap peningkatan kinerja manajerial melalui kepuasan kerja dan ketidakpastian lingkungan sebagai variabel moderating. Jurnal Akuntansi.

Bangun, A. (2009). Pengaruh Partisipasi Dalam Penyusunan Anggaran Kejelasan Sasaran Anggaran Dan Struktur Desentralisasi Terhadap Kinerja Manajerial SKPD Dengan Pengawasan Internal Sebagai Variabel Pemoderasi (Studi Kasus Pada Pemerintahan Deli Serdang), Thesis UNSUT Medan. Jurnal Akuntansi.

Boangmanalu, Y. S. (2014). PENGARUH PARTISIPASI PENYUSUNAN ANGGARAN, 
UMPAN BALIK ANGGARAN, DAN MOTIVASI TERHADAP KINERJA MANAJERIAL SKPD PADA PEMERINTAH KABUPATEN PAKPAK BHARAT. Undergraduate thesis, UNIMED. Jurnal Akuntansi. http://digilib.unimed.ac.id/id/eprint/14124

Brownell, P. dan M. M. (1986). Budgetary Participation, Motivation, and Managerial Performance. The Acccounting Review. The Acccounting Review, Vol. LXI (, 587600.

Dido, P. S. (2011). Pengaruh Budgetary Goal Characteristic Terhadap kinerja aparat Pemerintah Daerah Kota Padang Sumatra Barat. Jurnal Akuntansi.

Fransisca, A. A. S. (2012). Pengaruh Karakteristik Tujuan Anggaran Terhadap Kinerja Aparat Pemerintah Daerah Pada Satuan Kerja Perangkat Daerah Kota Yogyakarta. Jurnal Akuntansi.

Ghozali. (2018). 9, Aplikasi Analisis SPSS program IBM SPSS 25 Edisi (Badan Pene). Grafindo Persada.

Indriasari, D. dan E. N. (2008). Pengaruh Kapasitas Sumber Daya Manusia, Pemanfaatan Teknologi Informasi dan Pengendalian Intern Akuntansi Terhadap Nilai Informasi Pelaporan Keuangan Pemerintah Daerah (Studi pada Pemerintah Kota Palembang dan Kabupaten Ogan Illir). Simposium Nasional Akuntansi.

Istiyani. (2009). Pengaruh Karakteristik Tujuan Anggaran Terhadap Kinerja Aparat Pemerintah Daerah. Tesis. Universitas Sebelas Maret: Surakarta. Jurnal Akuntansi. Kenis, I. (1979). Effects of Budgetary Goal Characteristics on Managerial Attitudes and Performance. The Accounting Review, 707-721.

Mardiasmo. (2009). Otonomi dan Manajemen Keuangan Daerah (ANDI (ed.)).

Muthaher, O. (2007). Pengaruh Partisipasi Penyusunan Anggaran Terhadap Kinerja Aparat Pemerintah Daerah: " Budaya Organisasi dan Komitmen Organisasi sebagai Variabel Moderatin. Simposium Nasional Akuntansi $X$.

Naipospos, H. (2015). Pengaruh Partisipasi Anggaran, Kejelasan Sasaran Anggaran Dan Evaluasi Anggaran Terhadap Kinerja Aparat Pemerintah Daerah (Studi Empiris pada SKPD Kota Pekanbaru). Jom FEKON, Vol. 2 No.

Nina, G. (2014). PENGARUH KARAKTERISTIK TUJUAN ANGGARAN DAN KEADILAN PROSEDURAL TERHADAP KINERJA APARAT PEMERINTAH DAERAH (Studi Empiris Pada SKPD Pemerintah Kabupaten Lima Puluh Kota). Jurnal Akuntansi, 1-14.

Nugraeni. (2015). faktor-faktor yang mempengaruhi kinerja manajerial satuan kerja perangkat daerah (SKPD) pemerintah kota magelang. Jurnal Akuntansi. 
Purwandani, T. (2012). Analisis Pengaruh Partisipasi Penyusunan Anggaran terhadap Kinerja Aparat Pemerintah Daerah: Budaya Organisasi dan Komitmen Organisasi sebagai Variabel Moderating Survei pada Karyawan Pemda Kabupaten Klaten. Jurnal Akuntansi.

Sari. (2020). Pengaruh Karakteristik Tujuan Anggaran Terhadap Kinerja Aparat Pemerintah Daerah Pada Satuan Kerja Perangkat Daerah Kabupaten Bantul. Jurnal Akuntansi \& Manajemen Akmenika, Vol. 17 No, 1-18.

Sekaran, U. (2008). Metodologi Penelitian Untuk Bisnis. Selemba Empat.

Sisdyani. (2016). Pengaruh Akuntabilitas, Kejelasan sasaran Anggaran Dan Partisipasi anggaran Pada Kinerja Manajerial Di SKPD Kota Denpasar. Jurnal Akuntansi \& Keuangan.

Solina, M. (2014). Pengaruh Akuntabilitas Publik, Partisipasi Penyusunan Anggaran, Kejelasan Sasaran Anggaran dan Struktur Desentralisasi terhadap Kinerja Manajerial Pada Skpd Kota Tanjungpinang. Jurnal Ekonomi, Vol 20, 1-49.

Sugiyono. (2009). Metode Penelitian Kuantitatif Kualitatif dan RD. Bandung: Alfabeta.

Sugiyono. (2015). Metode Penelitian Kuantitatif, Kualitatif dan R \& D. Alvabeta. alfabeta. Sujana. (2014). PENGARUH AKUNTABILITAS, KEJELASAN SASARAN ANGGARAN DAN PARTISIPASI ANGGARAN TERHADAP KINERJA MANAJERIAL SATUANKERJA PERANGKAT DAERAH(Studi Empiris pada Satuan Kerja Perangkat Daerah Kabupaten Buleleng). E-JournalS1 Ak Universitas Pendidikan Ganesha, Volume $2 \mathrm{~N}$. https://doi.org/http://dx.doi.org/10.23887/jimat.v2i1.3408

Syafrial. (2009). Pengaruh Ketepatan Skedul Penyusunan Anggaran, Kejelasan Sasaran Anggaran, dan Partisipasi Penyusunan Anggaran terhadap Kinerja Manajerial SKPD pada Pemerintah Kabupaten Sarolangun. Tesis. Sekolah Pascasarjana Universitas Sumatera Utara. Jurnal Akuntansi.

Taufik. (2016). Pengaruh Karakteristik Tujuan Anggaran Terhadap Kinerja Aparat Pemerintah Kota Pekanbaru Dengan Sikap Aparat Pemerintah Sebagai Variabel Intervening. Jurnal Akuntansi, Vol. 4, No.

Vince. (2016). Pengaruh budaya organisasi, locus of control, stres kerja terhadap kinerja aparat pemerintah daerah dan kepuasan kerja sebagai variabel intervening. Jurnal Manajemen, Vol. XX, $N$.

Wahyuni. (2016). Analisis Kinerja Aparat Pemerintah Daerah (Studi Empiris Pada Pemerintah Kabupaten Bengkalis). Jurnal Inovasi Dan Bisnis, Vol. 4, No, 105-112. 
endang.sri@polbeng.ac.id

Widiyastuti. (2015). pengaruh Partisipasi penyusunan anggaran, kejelasan Anggaran, dan Profesionalime Sumber Daya Manusia Terhadap Kinerja Manajerial. Jurnal Akuntansi.

Widyarini. (2015). Pengaruh Partisipasi Penyusunan Anggaran, Kejelasan Sasaran Anggaran dan Profesionalisme Sumber Daya Manusia terhadap Kinerja pemerintah daerah. Jurnal Akuntansi. 